\title{
Rethinking Socialization Research through the Lens of New Materialism
}

\section{Grit Höppner* \\ Institute of Sociology, Westfälische Wilhelms-Universität Münster, Münster, Germany}

In recent decades, socialization research appears to have suffered the loss of its former capacity to explain the processes of becoming a socialized subject in a social environment. In this article, I review socialization theories taking into account assumptions regarding human subjects and their social environments. I confront them with the idea of rethinking dualisms, ontologies, and agencies addressed by the field of new materialism. I propose a new materialist-inspired socialization theory that assumes that humans, knowledge, and material environments become inseparable parts of (gendered) socialization processes in a world of constant change. This approach contributes to socialization theory and methodology because it illustrates precisely how humans and non-humans coproduce socialization in situated material-discursive processes.

Keywords: socialization, new materialism, dualisms, onto-epistemologies, agencies, non-human

\section{INTRODUCTION}

Socialization theories explain the process of the individual development of a human personality within a social environment, with specific living conditions (Hurrelmann and Bauer, 2015: p. 156). They show that individuals acquire language, knowledge, social skills, norms, values, and customs that are necessary for participating in and integrating into a group or community. Socialization is a combination of willed conformity and externally imposed rules, mediated by the expectations of other persons. Thus, socialization influences the socio-structural organization of a common existence, and simultaneously attains cultural and social continuity (White, 1977; Grundmann, 2006; Hurrelmann, 2009). In recent decades, however, socialization research has apparently suffered the loss of its former capacity to explain the processes of becoming a socialized subject in a social environment. ${ }^{1}$ This development is remarkable since socialization processes are still of great importance in research fields in the social sciences, for example, in governmentality studies (e.g., Bröckling, 2007), studies of social work (e.g., Böhnisch et al. 2009), studies of age (e.g., Schroeter, 2012), and gender (e.g., Gildemeister, 2008). Scholars of socialization research explain this development by identifying outdated approaches, missing theoretical and methodological discussions, and a lack of uniform terms and models (Geulen, 2004; Ricken and Wittpoth, 2017). Although this critique does not apply to all socio-scientific socialization theories, it is certainly clear that there is ambivalence between attempts to broaden the methodology of socialization research and a feeding back in corroborating new insights with the help of traditional socialization terms and models. Many scholars of socialization research seem to block out current performative and material accounts that would help the effort to rethink socialization processes in terms of ongoing material-discursive co-formations

${ }^{1}$ I thank Matthias Grundmann (Westfälische Wilhelms-Universität Münster, Germany) for this hint and for helpful comments on an earlier version of this paper. 
and agencies. Considering these analytical perspectives can help to unfold the complexity of becoming socialized in a world of constant social change.

In this article, I focus on a nexus of theories called new materialism that is often discussed in gender studies but has not yet caught the attention of socialization theory. New materialism is a recent term (Dolphijn and van der Tuin, 2012) that subsumes several performative and materialist theories, such as the agential realism of Barad $(2003,2007)$, the Deleuzian materialism of Braidotti $(2011,2013)$, and the posthumanism of Haraway (2007). New materialism enables a paradigm shift away from determinism and constructivism toward performativity and materialism (Barad, 1996; van der Tuin, 2008; Dolphijn and van der Tuin, 2012; Coole, 2013) and criticizes poststructuralist theories for considering language and thus the discursive nature of research but rarely its material processes (Barad, 2003). When I use Dolphijn and van der Tuin's (Dolphijn and van der Tuin, 2012) term, "new materialism," the intention is to highlight the need to bring back to discourses on the body-and thus to socialization theory - the materiality of humans and their material environments under specific conditions. These conditions refer to a particular understanding of materiality. Materiality is neither an essential element nor a discursive effect but an ongoing material formation and discursive construct, co-constituting in reference to its material environments. That is, socialization occurs neither solely through the agency of humans, their abilities and experiences nor solely through their environments. New materialist theories presume rather that humans, knowledge, and environments are essential parts of socialization processes. This understanding informs traditional ways of thinking of dualisms, ontologies, and agencies in socialization theory (cf. Hinton and van der Tuin, 2014).

My intention, in using the term "new materialism," is to map the material-discursive complexity of socialization processes to offer a more nuanced understanding of the many facets of socialization from a micro-sociological perspective. Thus, my intention differs from the aims of the theoretical framework called materialist feminism, which uses Marx's historical materialisms as a means to analyze specifically material social inequalities such as patriarchy (e.g., Delphy, 1980; Hennessy and Ingraham, 1997). Moreover, my intention is not to trace the genealogy of the term "new materialism" and to evaluate either if the feminist content of new materialism is in a process of being dismantled or if the positioning as new materialist scholar causes a specific feminist identity as political and ethical. These important questions are currently discussed elsewhere by using the term "feminist new materialism" (Hinton and van der Tuin, 2014). In this article, I will instead show that new materialism makes a fruitful contribution to the discussion on socialization processes because it helps to clarify how materialities of socialization are coproduced, how they interact with each other, which processes of everyday life actually count as processes of socialization, and how socialization processes are gendered processes. Although work on the relevance of materialities of socialization and on the complexity of socialization processes is not new (e.g., Blumer, 1969; Bronfenbrenner, 1979), I will show that new materialism opens up novel questions for socialization scholars to ask, and thus new ways to theorize and research (gendered) socialization (cf. Fox and Alldred, 2016). Therefore, I suggest that we call into question not only the dualism of nature vs. culture but also the dualism of human vs. non-human to displace the human as a central focus of study and think more about the interactions between humans and the inanimate. I will show that to rethink the dualism of human vs. non-human enriches our understanding of socialization as a posthuman process.

In the following sections, I review socialization theories in view of common assumptions about humans and their environments, and confront them with new materialist assumptions about dualisms, onto-epistemologies, and agencies. The aim is to develop methodological ideas for new materialist-inspired socialization research. I conclude with an assessment of the contribution that new materialism provides to socialization theory and methodology.

\section{RETHINKING THE HUMAN SUBJECT AND SOCIAL ENVIRONMENT OF SOCIALIZATION THEORY}

In socialization theories, the subject is central: the subject is the essential human entity that carries out and expresses socialization processes within the scope of a social environment. In this work, I contrast these assumptions in some detail with those of new materialism (e.g., Barad, 2003, 2007; Braidotti, 2011; Dolphijn and van der Tuin, 2012). First, the new materialist assumption of rethinking dualisms briefly shows that several dualisms essentially structure socialization theories and that the classifying thinking in dualisms makes it impossible to map the complexity of socialization processes. I continue with the new materialist assumption of rethinking human entities to better understand both the process of becoming socialized and the influence of the material environment on this development. Finally, the new materialist assumption that agency is coproduced in material-discursive processes helps to show that the human subject is only one in the many participants that produce socialization processes.

\section{Dualisms}

Dualistic thinking assumes the existence of binary oppositions between two separate areas, such as the opposition between activity and passivity - a familiar dualism in socialization research. Traditional theories described socialization as a process in which persons take over norms, values and customs, and thereby learn the skills and habits that are necessary for participating in society (e.g., Hurrelmann and Ulich, 1980). The subject, in the socialization process, was in fact an object-passively adopting socially requested actions and orientations as part of accepting a given destiny. In recent decades, this understanding has changed to a definition of socialization in which individual developments are central. From this new perspective, socialization is an active process of learning, educating, and changing, that is, each person is presumed to actively influence her or his own developments (e.g., Hurrelmann et al., 2008). Thus, the individual in socialization research has become an active, autonomous acting subject (Geulen, 2004). Few scholars of socialization research currently 
discuss to what extent individuals are in fact active and autonomous. They argue that the limited focus on activity and autonomy blocks out enhancements in socialization research (Ricken and Wittpoth, 2017: p. 229). Under discussion is the term of selfsocialization and its inherent reductionism that does not consider heteronomy and thus power relations and processes of repression that interpenetrate western societies (Bauer, 2002: p. 125f).

Both socialization scholars and new materialist scholars negotiate the "space" between corporality and sociality-however, with different focuses. Socialization theories discuss the dualism of subject vs. structure. Based upon Pierre Bourdieu's idea of the habitus, Norbert Ricken and Jürgen Wittpoth criticize the connected assumption of mutual relationships that seemingly mediate between the two separate realms of "inside" and "outside." Instead of thinking in such a dualistic way, they suggest asking: "In which medium does socialization proceed?" (Ricken and Wittpoth, 2017: p. 231, author's translation). Thus, they broaden the analytical perspective in terms of the performative matter of socialization-an idea that is also relevant for new materialist approaches.

New materialist scholars have repeatedly pointed to the fact that dualisms reduce the complexity of the natural-cultural world and intensify social inequalities (e.g., Braidotti, 2011; Schmitz, 2012; Shildrick, 2013; Höppner, 2015b). Thus, they attempt to rethink especially the dualisms of nature vs. culture and human vs. non-human (Haraway, 1991; Barad, 2003; Coole, 2013; Schadler, 2016)-both of which inform socialization theories because socialization theories have not yet fully discussed the functions and consequences of these dualisms. The following example clarifies this argument. Schadler $(2013,2016)$ has impressively shown that socialization research distinguishes between "a presocial biological body and an immaterial social personality," and thus "between a biological and a social birth" (Schadler, 2016: p. 506). In her research on the formation of the nuclear family during the transition to parenthood, she demonstrates that socialization processes in families are instead both cultural procedures that start even before the physical pregnancy and material processes that include human bodies and include things and technologies during the whole transition process (Schadler, 2013). Thus, socialization is not an "epigenesis" (Ricken and Wittpoth, 2017: p. 228), Schadler argues, but rather a natural-cultural "becoming with" (cf. Schadler, 2016: p. 507). Schadler highlights two aspects in this work. First, she shows that socialization processes do not exclusively require humans; rather, they require numerous (non-) human participants that coproduce socialization processes. Second, socialization research assumes a difference between nature and culture-a dualism that feminist sociologists have been discussing since Ann Oakley (1972) suggested a difference between a natural "sex" and a social "gender" and regarding the attributions of female corporality and male sociality. New materialist scholars have rethought the dualisms of sex vs. gender and nature vs. culture by introducing the idea of embodying (Schmitz and Degele, 2010; see also Witz, 2000: p. 10, who points to the need to consider the "fleshy matters of embodied sociality"): sex and gender cannot be separated because they coproduce each other. For example, Schadler (2013) (pp. 201-213) shows that the determination of the sex of a fetus in the belly simultaneously initiates gendered processes (e.g., searching for the baby's name, buying clothes, and furnishing the nursery in the "right" color), and these processes themselves determine the gendering of the fetus. Gendered socialization continues during our lifespan through the assumptions and expectations that we experience and embody, the way we gesture and move, the objects that we use and that we do not use, and so forth. In an empirical study, new materialist scholars do not focus on the outcomes of gendered socialization processes. Rather they take into account all those material processes that are linked to sex and gender and identify and systematize all those factors and their interdependencies that coproduce gendered socialization processes. It is not, then, the observation that someone has a male muscle formation that would interest these scholars, but rather the precise material-discursive practices (e.g., physical training, usage of medicine, individual development, feeding, and talking with others about muscles), that condition that muscle formation and through which muscles are linked to masculinity rather than to femininity in our society. Mapping these processes in detail helps us to understand why societies and cultures maintain a certain degree of stability in social formations such as ideas of gender, and how these formations in turn help to preserve gendered inequality and support those who wield power (cf. Fox and Alldred, 2016: p. 9). Thus, in a new materialist perspective, sexing and gendering can be reframed as a material-discursive process that coproduces a specific kind of socialization. This kind of socialization not only reinforces the entanglement of sex with gender but also provides information on the body's sex and gender to the environment, which in turn reacts to the information in a specific-gendered-way.

Consequently, one central tenet of new materialist-inspired socialization research is to deconstruct dualisms. This idea does not mean that dualisms can be dissolved, since reconfigurings of the natural-cultural world produce ongoing differentiations (Barad, 2007). Rather, to better understand socialization processes, dualisms have to be reflected in terms of (1) the boundaries and connected ascriptions that come along with dualisms during an investigation, (2) the specific contexts in which the boundaries and ascriptions occur, (3) the reasons for their use, and (4) the consequences that result from them. Reflections differ on a methodological and an analytical level. A methodological reflection on dualisms could take into account techno-scientific practices that might have influenced data generation (e.g., the extent to which the way of behaving and speaking during data generation has triggered the reproduction of internalized norms on behaving and speaking as a woman or a man). An analytical reflection on dualisms could refer to the ways of "doing socialization" in praxis by verbally referring to dualisms or by corporally producing, for example, dualistic ideas of the body such as femininity or masculinity (cf. Irni, 2010; Hinton, 2013; Höppner, 2015a, 2015b).

\section{Onto-Epistemologies}

I want to start this section with the common definition of socialization that I mentioned in the Section "Introduction." Socialization is the "process of the genesis and development of human personality in mutual dependence on and in interchange with historically mediated social and material general living conditions" (Hurrelmann and Bauer, 2015: p. 156, author's 
translation). This definition identifies the interconnection (and thus the "space") between the individual and society as the central object of socialization research. The development of human personality and becoming a socialized subject is relevant to socialization research, and so are the processes of collectivization and sociality (Beer and Bittlingmayer, 2008). This definition, however, has to be clarified regarding the term "human personality" and its relation to the material environment and regarding the temporality of "human personality."

Scholars define the term "human personality" as both stimulator and result of socialization and thus center socialization exclusively in the human body. The personality of a person comprises all individual psychic features that differ from those of other persons and are relatively stable over time, e.g., temperament, attitudes, values, motives, emotions, behaviors, and cognitions (e.g., Engler, 2008: p. 82). The term "human personality" supposes both a socialized human and an enclosed body, comprising a social persona and a physical, prosocial biological body. Through the processes of socialization, a person does indeed change over the course of her or his lifespan but unmistakably remains who s/he is-a human body with clear limitations, distinguishable from others.

In a new materialist perspective, not only the normative coding of a body as socialized or as not socialized is up for critical discussion but also the question of what $a$ body of socialization processes actually is. New materialist scholars assume that human bodies are not exclusively material or exclusively discursive but rather material-discursive co-formations, as are meanings, norms, values, customs, and structures (Barad, 2003, 2007). It becomes clear that the boundary between nature (e.g., the human body and the material environment) and culture (e.g., meanings, norms, and values) is in fact not as clear as assumed traditionally. New materialist scholars point to the fact that nature does not exist before socioculture, and socioculture does not exist before nature. Rather, nature and socioculture constitute each other in agential practices in which several materialities are coproduced; since both sociocultural and material factors influence social development, they stress the inseparability of nature and culture (van der Tuin, 2008; Schmitz and Degele, 2010). Two examples might help to clarify this argument. Bodies, for example, do not end at the skin because the skin acts as an only apparently visible corporal boundary. Bodies are inseparable from cultural and social processes; they are already materially connected to these meaning-making processes because they emerge within the very same practices (Höppner, 2015b). Donna Haraway's writings about scientific research, to give another example, show that nature is not discovered. Rather, nature is culturally constructed and materially arranged in techno-scientific practices, in which humans, instruments, and computers are involved and interact. She illustrates this argument by pointing to the production of species in the laboratory; their seemingly natural differences are made in boundary-drawing research practices. She concludes that nature is both a thoroughly natural-cultural matter and a "situated knowledge" because it is produced by specific actors, in specific times, in specific places (Haraway, 1988). Barad (2003, 2007) (Section "Agencies") argues in a similar way when she emphasizes that it is vital to consider the research apparatus of a project, e.g., all those material-discursive practices that draw boundaries and thus produce particular findings.

Closely connected to the rethinking of nature and culture is the rethinking of human and non-human to question the differentiation in human and non-human and also the hierarchic conceptualization of humans above non-humans. Haraway (1989), for example, deconstructs this difference by pointing to the techno-scientific practices that help to "make" humans by separating them from other species in the laboratory. Since research does not present the process of separation but only the finally produced entities, presented findings seem to be "naturally," e.g., biologically determined. According to Haraway, the separation into human and non-human is an artificial construction.

Rethinking the dualisms of nature vs. culture and human vs. non-human helps to understand that not only humans "produce" socialization but also that socialization is a coproduction of several material-discursive formations and thus a posthuman process. Socialization does not happen on a human's own terms but through contact with the material-discursive environment in the form of a "becoming with" humans, things, technologies, spaces, knowledge, among others (cf. Schadler, 2016: p. 507). In turn, human-thing-technology-space-knowledge networks produce specific kinds of socialization processes.

New materialist scholars use the term "onto-epistemologies" (Barad, 2003: p. 829) to highlight the idea that being and knowing are not isolatable, but that they are mutually entangled with and thus co-constitute each other. We obtain knowledge-e.g., on sex and gender-because we are part of a gender-structured world. At the same time we are "our" sex (or try to undermine it), thus reproducing the gender order of the world. Gendered socialization usually comprises non-human elements, for example, clothes and accessories (cf. Barad, 2003: p. 829). For this reason, new materialist scholars assume human and non-human bodies to be temporary matterings with altering boundaries (Barad, 2003, 2007), entangled in "manifold smaller and larger assemblages" (Coole, 2013: p. 455). They rethink human bodies, with their seemingly clear and fixed boundaries in relation to non-human bodies. In this understanding, bodies are flexible. However, flexible bodies are not extended by objects, e.g., a walking stick, or changed by technological alteration, e.g., through the insertion of a cardiac pacemaker. Rather, bodies are flexible when new socialization processes are coproduced by the use of objects or the insertion of technologies within person-objects-technology networks (cf. Haraway, 1989, 1991).

Since new materialist-inspired socialization research questions what a human body actually comprises, it becomes clear that temperament, attitudes, values, motives, emotions, behaviors, and cognition are not preexisting kinds of representation but rather dynamic co-formations of meanings and kinds of materiality, which emerge in material-discursive practices. A "philosophy of life" that guides people, legs that walk in an individual way or the glasses that mark a person distinctively are essential onto-epistemologies of socialization networks. From a posthuman perspective, it is not possible to analyze "human personality" independent of its social-material context. The value of expanding the "human personality" concept to temporarily dissolve static limitations and reshape boundaries between humans 
and non-humans is that all participants can be considered that influence socialization processes.

To consider the onto-epistemologies that take part in and thus coproduce socialization processes, researchers have to focus on humans, environments, structures, and assumptions linked to micro-socialization processes. Which onto-epistemologies of socialization networks researchers take into account and thus consider as influencing socialization is an empirical question. Both participants and researchers in a study serve as "translators" of the processes that happen within socialization networks because they verbally and simultaneously non-verbally articulate (gendered) experiences, options, motions, and feelings. Through references to others, they form and maintain boundaries and thus mark socialization networks (cf. Höppner, 2015b).

New materialism does not evaluate a process of everyday life as a process of socialization by focusing on the success of fulfilling norms but rather by focusing on the development of "human personality" in terms of temporality. It is common sense that socialization is a lifelong process (e.g., Geulen, 2004: p. 7; Ricken and Wittpoth, 2017: p. 228). However, scholars of socialization research especially analyze the so-called primary socialization (during this period children learn values, attitudes, and actions that are appropriate for members of a society) and secondary socialization (during this period children and teenagers learn what an appropriate behavior as a member of a smaller group within society is). Thus, the focus is particularly on childhood (Piaget, 1971; Strand, 2000; Hopf, 2005; Tietze, 2008; Park et al., 2014), adolescence (Albert et al., 2010; Eckstein and Noack, 2016), and family (Bronfenbrenner, 1986; Arnett, 1995; Lüscher and Fischer, 2014; Grundmann and Wernberger, 2015). The so-called third socialization period, during which adults learn to handle changes and transitions, is rarely considered. Analyses in view of transformation processes due to the start of retirement and the move into a retirement home remain the topic of the sociology of aging and sociology of gender (Depner, 2015; Höppner, 2017). Important findings on social learning processes and development of abilities in the aging population remain largely unconsidered.

While traditional socialization theories consider an adult to be the product of a past child, recent theories have developed a micro-sociological perspective on socialization since they consider socialization to be a social praxis that alters over time (Grundmann, 2006). Matthias Grundmann takes into account both how interactions between persons form personal courses of actions and dispositions (e.g., personal manifestations) and how cultural ideas and societal resources of lifestyle flow into interactions (social manifestations). This process-related conceptualization of socialization considers the alterability and thus the temporal dimension of socialization.

New materialist scholars further concretize the temporal dimension. They point to the need to consider both the historical and genealogical processes of becoming. Braidotti's "nomadic subject" (Braidotti, 2011) is situated in a world of permanent social change, including the coproduction of power relations and requests for alterability and adaptation. From the perspective of this conception, socialization is always within history and genealogy. On the one hand, socialization does not start at a zero-point since it refers to former societal events, political decisions, and already negotiated meanings and ascriptions-e.g., the past is constitutive for the present and the future. Thus, a new materialist account can inspire socialization research by questioning the assumptions, prejudices, and hopes that are constituted by socialization processes and the social hierarchies that socialization processes maintain or modify. On the other, socialization is a biographical process, coproducing experiences, opinions, and moods, among other things. To analyze socialization processes it does not suffice to "zoom into" a snapshot of socialization. Rather, the dynamic process of becoming socialized is to be taken seriously (cf. Schmitz and Degele, 2010).

New materialist-inspired socialization research considers that a present form of socialization is the result neither simply of the past nor simply of societal structures. Rather, it understands socialization as an ongoing material-discursive process that reshapes and is reshaped through experiences, memories, and the understanding of ourselves, and thus through the stories that we tell and embody. These stories, however, are specific since they are located within historical, social, cultural, and biographical contexts (cf. Jackson, 2001: p. 288). Becoming socialized means undergoing a continual material-discursive transition that coproduces fairly stable "units" (e.g., attitudes and values) and transformations (e.g., bodily changes). Researchers have several options for generating and analyzing such ongoing transitions. In a first step, researchers have to define their understanding of socialization: do they link socialization to the so-called socialization instances (e.g., parents, school, and peer group), to the development of gendered selves, to the age? Or do they understand socialization in a broader sense, which implies that any situation in everyday life can have socializing effects, independent of whether a socializing situation happens once (e.g., in the case of a traumatic situation) or several times (e.g., routine and customs). In a second step, researchers working empirically should focus on the process of data collection. In qualitative research they could use interviews or observations to describe verbal and simultaneously non-verbal articulated continuities and discontinuities as well as the social hierarchies that are established through these practices (Höppner, 2015b). As an alternative to the description of such situational processes including practices and onto-epistemologies that form, maintain, or modify socialization networks, a research project could repeat interviews and observations to generate findings on becoming socialized as part of the life course of study participants.

\section{Agencies}

Agency is a central term in socialization theory, describing the individual's capacity to act within societal structures. Theories tend to deal with the options that individuals have due to their own resources (e.g., abilities and biographical experiences) and how they use these resources in response to societal expectations (Raithelhuber, 2012) and sociocultural conditions (Sewell, 1992). Scholars investigate how individuals cope with social change and personal transitions. Böhnisch et al. (2009) differentiate between a regressive form of agency (e.g., to manage everyday life needs) and an extended form of agency, which comprises the capacity to reflect on one's own actions, e.g., in terms of social and ecological sustainability. While the capability approach investigates conditions such as education and wealth for their ability to empower 
people to live an independent life and to participate in society (Sen, 1993), a capability approach that is informed by socialization theory considers individuals' everyday life experiences in the context of social relations and options in acting and transforming living conditions (Grundmann, 2010). Socialization theories do not disregard the relationship between the structure and content of actions (Emirbayer and Mische, 1998; Helfferich, 2012), nor do they define agency as a human capacity. Rather, agency is a result and feature of socialization processes, which performs due to biographical experiences, is recognizable in options of action, and is predictable for future actions regarding the realization of aims (Grundmann, 2006, 2017). Thus, agency is not separable from the human body (Noland, 2009).

New materialist scholars also argue that agency is not an attribute of people or objects (e.g., Barad, 2007: p. 194). However, since agency is a part of "ongoing reconfigurings of the world" (Barad, 2003: p. 818), new materialist scholars conceptualize agency as proceeding in material-discursive processes, deriving from differentiation processes. Humans and other participants in socialization are differentiated in these posthuman processes, thus, they are considered to be one agential participant that coproduces the boundaries of socialization (cf. Barad, 2003; van der Tuin, 2008; Schmitz and Degele, 2010). That is, not only are humans agential in the sense that they ascribe meanings to objects, technologies, and animals; objects, technologies, and animals simultaneously provoke meanings in humans within the scope of socialization processes. Since new materialist scholars do not center agency in a single human who has a preexisting disposition in processing meaning and knowledge, they refuse to think of a human as origin or result of agency, as is common in a concrete way of thinking that argues for childish, youthful or adult forms of agency. In new materialism, agency is negotiated by heterogeneous "mediums." New materialist scholars ask: who actually socializes whom or what-does the wheelchair socialize the person or does the person in fact socialize the wheelchair? In this way, they decentralize the human actor and contribute to socialization theory a concept of shared agencies that are material-discursively coproduced within socialization networks (cf. Mol, 2002; Barad, 2003; Alaimo and Hekman, 2008). Agency has multiple locations and thus influences a shared existence in different ways. A posthuman understanding of agency redefines humans and structures that are produced by humans in defining configurations such as the family (Schadler, 2016).

To map such collective processes of agency (Coole, 2013) and thus all the onto-epistemologies and practices that produce socialization processes, Barad (2007) (pp. 218-220) insists on considering the research apparatus - that is, a specific entanglement of material-discursive practices within the scope of a research project. A research apparatus procures the conditions for the production of agency. Related to socialization, the apparatus of a research project is agential in the sense that it produces socialization processes that did not exist before the data were generated; instead, the data are coproduced through relations between materialities and meanings in the specific scientific context. For example, a socialization process such as becoming feminine or masculine is coproduced in a particular manner during data generation. The idea of femininity or masculinity is inseparably entangled with further socialization processes, such as socialization processes of age, health, and class: they co-constitute each other within a research apparatus.

The options to analyze agency within the scope of data generation depend on the scientific discipline. Barad (2007), for instance, focuses on ultrasound technology and bases her definition of agency on an understanding of quantum physics. A way to consider agency in socio-scientific research is to focus on interactions between humans and also on posthuman interactivities - that is, the way people articulate their memories of objects or the way they describe the use of objects-and record and transcribe bodily comportment such as laughing, pausing, and a specific way of speaking - to include these articulations as data in the analysis of utterances (Höppner, 2015a, 2015b, 2017).

Considering the apparatus of socialization processes enables researchers to ask: How is agency produced and can the production of socialization be understood as a shared performativity of agency? What does it mean to be agential within socialization processes? What kinds of agency do socializing people actually have in different social fields of action? Are there identifiable gender-specific forms of agency?

Barad also suggests thinking of the consequences that result from the production of agencies in a project. In contrast to Cartesian cuts, which presume the prior existence of and distinction between researcher and researched, subject and object, human and human, human and non-human, Barad (2003) (p. 815) uses the idea of "agential cut" to consider boundary drawings that coproduce particular kinds of socialization. She thus highlights the need to reflect all decisions that are made during projects because they influence findings significantly. Such reflections comprise not only the choice of a method to generate data and a method to analyze them but also the decision concerning whom to include in a sample and the decision to use a specific theoretical framework and method of transcription. These decisions influence the configuration of a research apparatus and thus the findings.

To consider agency in a project means to consider the processes of posthuman agency on an analytical level. When it comes to the methodology it means to assume the responsibility as a researcher to present findings transparently, which means contextualizing findings to include situational effects, disciplinary features, and developments within the scope of a research project.

\section{CONTRIBUTION OF NEW MATERIALIST IDEAS TO SOCIALIZATION RESEARCH}

In this article, I have suggested adding new materialist ideas concerning dualisms, onto-epistemologies, and agencies to socialization theory and methodology. I have elucidated both how the decentralization of the human actor can help to map the complexity of (gendered) socialization processes in terms of situated practices and their agential participants, and how this mapping can be methodologically grasped. From the perspective of new materialism socialization is not limited to humans, their abilities, experiences, and social environments. What actually counts as socialization are ongoing processes of boundary 
drawing, through which materialities and their relations are formed and provided with (gendered) meanings. By considering the multiple entanglements of people, all the activities they are part of, and all the participants that are temporarily linked to them, new materialist-inspired socialization research can advance the understanding of socialization processes, how they in fact develop and become durable. New materialist theories base themselves on non-reductionism and take into account the complex relations of everyday life, e.g., the connection between technologies and family structures (Schadler, 2016). Further processes that can become visible through the lens of new materialism could enrich the research field of socialization and aging, for instance by studying the relationships between spaces, architectures, commodity items, and "becoming old." On the other hand, new materialism can offer new insights into already well-investigated forms of child and teenager socialization, e.g., taking into account the effects that pets, toys, and smartphones have on relationships between parents, peers, and teachers or on the development of gendered preferences. A reductionist account can measure only parts of socialization processes because it focuses on selected forms of socialization and meanings, which in turn are considered to be fairly fixed and homogenous-forms such as childhood, adolescence, and old age. New materialist theories do not assume socialization as a linear course but as a coformation, proceeding within relational processes that constantly reshape socialization experiences.

What is new in a new materialist perspective are the ways in which scholars theorize and empirically analyze the connections between humans, objects, and technologies, among other things. For example, symbolic interactionism focuses on things and their functions within socialization processes (Blumer, 1969). Since, however, symbolic interactionism considers humans and things as separated entities, they exclude the value of investigating the processes of co-production and thus the posthuman processes that form, maintain, or modify socialization experiences. Ecological systems theory maps five environmental systems with which individuals interact and form relationships (Bronfenbrenner,

\section{REFERENCES}

Alaimo, S., and Hekman, S. (eds) (2008). Material Feminisms. Bloomington: Indiana University Press.

Albert, M., Hurrelmann, K., and Quenzel, G. (2010). 16. Shell Jugendstudie: Jugend 2010 [16th Shell Youth Study: Youth 2010]. Frankfurt am Main: Fischer.

Arnett, J. J. (1995). Broad and narrow socialization: the family in the context of a cultural theory. J. Marriage Fam. 57, 3. doi:10.2307/353917

Barad, K. (1996). "Meeting the universe halfway: realism and social constructivism without contradiction," in Feminism, Science, and the Philosophy of Science, eds L. H. Nelson and J. Nelson (London: Kluwer), 161-194.

Barad, K. (2003). Posthuman performativity: toward an understanding of how matter comes to matter. Signs J. Women Cult. Soc. 28, 801-831. doi:10.1086/ 345321

Barad, K. (2007). Meeting the Universe Halfway. Quantum Physics and the Entanglement of Matter and Meaning. Durham: Duke University Press.

Bauer, U. (2002). Selbst- und/oder Fremdsozialisation: Zur Theoriedebatte in der Sozialisationsforschung. Eine Entgegnung auf Jürgen Zinnecker. Zeitschrift für Soziologie der Erziehung und Sozialisation 22, 118-142.

Beer, R., and Bittlingmayer, U. H. (2008). "Die normative Verwobenheit der Sozialisationsforschung," in Handbuch der Sozialisationsforschung, eds K. Hurrelmann, M. Grundmann, and S. Walper (Weinheim: Beltz Verlag), 56-69.
1979). Similarly, new materialist scholars assume individuals to be producing contexts of socialization together with structural conditions. However, they perceive networks as being both stable enough to allow repetitions of practices in particular contexts and fluid enough to allow for constant transformations. Thus, they do not assume networks as being determined to socialization but rather show empirically what a system such as the family actually comprises in a particular context (Schadler, 2013, 2016).

Twenty-first-century geopolitical and socioeconomic structures require vital research that is able to grasp the complex connection between social changes and socialization. On the one hand, social changes flow in the physique, in somatic perceptions, and in bodily knowledge (e.g., on gender), and have material consequences, e.g., social inclusion or exclusion. On the other hand, socialization processes are not optional or random but linked to biographical experiences, locations as well as social, cultural, and economic structures that coproduce very specific ways of becoming socialized. New materialist-inspired socialization research takes into account such entangled microprocesses by mapping the situated knowledge (Haraway, 1988) that intensifies in material-discursive practices of socialization networks. In view of the inherent power relations of socialization, new materialistinspired socialization research is always political: which processes of socialization are given precedence depends on contemporary economic, environmental, geographical, and technological developments that require new accounts of nature, agency, and sociopolitical relationships (Coole and Frost, 2010). Ten years ago, Haraway (2007) stated, "we have never been human." In view of actual social changes, her statement was never more up to date than today. A new materialist-inspired socialization research would do justice to the world's complex material-discursive posthumanism.

\section{AUTHOR CONTRIBUTIONS}

$\mathrm{GH}$ is the sole author of this article and is responsible for its content.

Blumer, H. (1969). Symbolic Interactionism: Perspective and Method. New York: Prentice-Hall.

Böhnisch, L., Lenz, K., and Schröer, W. (2009). Sozialisation und Bewältigung. Eine Einführung in die Sozialisationstheorie der zweiten Moderne. Weinheim: Beltz Juventa.

Braidotti, R. (2011). Nomadic Subjects. Embodiment and Sexual Difference in Contemporary Feminist Theory, 2nd Edn. New York: Columbia University Press. Braidotti, R. (2013). The Posthuman. Cambridge: Polity Press.

Bröckling, U. (2007). Das unternehmerische Selbst - Soziologie einer Subjektivierungsform. Frankfurt am Main: Suhrkamp.

Bronfenbrenner, U. (1979). The Ecology of Human Development: Experiments by Nature and Design. Cambridge: Harvard University Press.

Bronfenbrenner, U. (1986). Ecology of the family as a context for human development: research perspectives. Dev. Psychol. 22, 723-742. doi:10.1037/ 0012-1649.22.6.723

Coole, D. (2013). Agentic capacities and capacious historical materialism: thinking with new materialisms in the political sciences. Millennium J. Int. Stud. 41, 3. doi:10.1177/0305829813481006

Coole, D., and Frost, S. (eds) (2010). New Materialisms: Ontology, Agency, and Politics. Durham: Duke University Press.

Delphy, C. (1980). A materialist feminism is possible. Fem. Rev. 4, 79-105. doi:10.2307/1394771 
Depner, A. (2015). Dinge in Bewegung - zum Rollenwandel materieller Objekte. Eine ethnographische Studie über den Umzug ins Altenheim. Bielefeld: Transcript.

Dolphijn, R., and van der Tuin, I. (2012). New Materialism: Interviews and Cartographies. Ann Arbor: Open Humanities Press.

Eckstein, K., and Noack, P. (2016). "Classroom climate effects on adolescents' orientations toward political behaviors: a multilevel approach," in Political Engagement of the Young in Europe: Youth in the Crucible, eds P. Thijssen, J. Siongers, J. van Laer, J. Haers, and S. Mels (New York: Routledge/Taylor \& Francis), 161-177.

Emirbayer, M., and Mische, A. (1998). What is agency? Am. J. Sociol. 103, 962-1023. doi:10.1086/231294

Engler, B. (2008). Personality Theories: An Introduction, 8th Edn. Boston, MA: Houghton Mifflin.

Fox, N. J., and Alldred, P. (2016). Sociology and the New Materialism. Theory, Research, Action. Los Angeles: SAGE.

Geulen, D. (2004). "Ungelöste Probleme im sozialisationtheoretischen Diskurs," in Sozialisationstheorie interdisziplinär. Aktuelle Perspektiven, eds D. Geulen and H. Veith (Stuttgart: Lucius \& Lucius), 3-20.

Gildemeister, R. (2008). "Doing Gender: Soziale Praktiken der Geschlechterunterscheidung," in Handbuch Frauen- und Geschlechterforschung: Theorie, Methoden, Empirie, eds R. Becker and B. Kortendiek (Wiesbaden: VS Verlag für Sozialwissenschaften), 137-145.

Grundmann, M. (2006). Sozialisation: Skizze einer allgemeinen Theorie. Konstanz: UVK Verlagsgesellschaft.

Grundmann, M. (2010). "Handlungsbefähigung - eine sozialisationstheoretische Perspektive," in Capabilities - Handlungsbefähigung und Verwirklichungschancen in der Erziehungswissenschaft, eds H.-U. Otto and H. Ziegler (Wiesbaden: VS Verlag für Sozialwissenschaften), 131-142.

Grundmann, M. (2017). "Agency und sozialisation," in Netzwerk, Kultur und Agency, ed. H. Loewenstein (Weinheim: Beltz Juventa).

Grundmann, M., and Wernberger, A. (2015). "Familie und Sozialisation," in Handbuch Familiensoziologie, eds P. Hill and J. Kopp (Wiesbaden: Springer VS Verlag), 413-436.

Haraway, D. J. (1988). Situated knowledges: the science question in feminism and the privilege of partial perspective. Fem. Stud. 14, 575-599. doi:10.2307/3178066

Haraway, D. J. (1989). The biopolitics of posthuman bodies: determinations of self in immune discourse. Differ. J. Fem. Cult. Stud. 1, 3-43.

Haraway, D. J. (1991). "A cyborg manifesto: science, technology, and socialistfeminism in the late twentieth century," in Simians, Cyborgs, and Women: The Reinvention of Nature, ed. D. J. Haraway (London: Free Association Books), 149-182.

Haraway, D. J. (2007). When Species Meet. Minnesota: University of Minnesota Press.

Helfferich, C. (2012). "Einleitung: Von roten Heringen, Gräben und Brücken. Versuch einer Kartierung von Agency-Konzepten," in Agency. Qualitative Rekonstruktionen und gesellschaftstheoretische Bezüge von Handlungsmächtigkeit, eds S. Bethmann, C. Helfferich, H. Hofmann, and D. Niermann (Weinheim: Beltz Juventa), 9-39.

Hennessy, R., and Ingraham, C. (1997). Materialist Feminism. A Reader in Class, Difference, and Women's Lives. New York: Routledge.

Hinton, P. (2013). The quantum dance and the world's 'extraordinary liveliness': refiguring corporeal ethics in Karen Barad's agential realism. Somatechnics 3, 169-189. doi:10.3366/soma.2013.0084

Hinton, P., and van der Tuin, I. (2014). Preface. Special issue 'Feminist Matters: The Politics of New Materialism. Women Cult. Rev. 25, 1-8. doi:10.1080/0957 4042.2014.903781

Hopf, C. (2005). Frühe Bindungen und Sozialisation: Eine Einführung. Weinheim: Beltz Juventa.

Höppner, G. (2015a). "Becoming with things," in Interviews: Materialisierungsprozesse von Wiener Renter_innen am Beispiel von Bergerzählungen. Body Polit. 3(6), 213-234.

Höppner, G. (2015b). Embodying of the self during interviews: an agential realist account of the non-verbal embodying processes of elderly people. Curr. Sociol. 65(3), 356-375. doi:10.1177/0011392115618515.

Höppner, G. (2017). "Alter(n) non-verbal verkörpern. Eine posthumanistischperformative Analyse des Körperwissens von Rentner_innen in Interviews," in Alter(n) und vergängliche Körper,. eds Keller, R. and Meuser M (Wiesbaden: VS-Verlag) 183-207.
Hurrelmann, K. (2009). Social Structure and Personality Development. Cambridge: Cambridge University Press.

Hurrelmann, K., and Bauer, U. (2015). "Das Modell des produktiv realitätsverarbeitenden Subjekts," in Handbuch Sozialisationsforschung, eds K. Hurrelmann, U. Bauer, M. Grundmann, and S. Walper (Weinheim: Beltz Juventa), 144-161.

Hurrelmann, K., Grundmann, M., and Walper, S. (2008). Handbuch Sozialisationsforschung. Weinheim: Beltz Juventa.

Hurrelmann, K., and Ulich, D. (1980). Handbuch der Sozialisationsforschung. Weinheim: Beltz.

Irni, S. (2010). Ageing Apparatuses at Work: Transdisciplinary Negotiations of Sex, Age and Materiality. Turku: Åbo Akademi University.

Jackson, S. (2001). Why a materialist feminism is (still) possible - and necessary. Womens Stud. Int. Forum 24, 283-293. doi:10.1016/S02775395(01)00187-X

Lüscher, K., and Fischer, H. R. (2014). Ambivalenzen bedenken und nutzen. Familiendynamik 38, 81-95.

Mol, A. (2002). The Body Multiple: Ontology in Medical Practice. Durham: Duke University Press.

Noland, C. (2009). Agency and Embodiment. Performing Gestures/Producing Culture. London: Harvard University Press.

Oakley, A. (1972). Sex, Gender and Society. Towards a New Society. London: Maurice Temple Smith Ltd.

Park, H., Coello, J. A., and Lau, A. S. (2014). Child socialization goals in East Asian versus Western Nations from 1989 to 2010: evidence for social change in parenting. Parent. Sci. Pract. 14, 69-91. doi:10.1080/15295192.2014. 914345

Piaget, J. (1971). The Construction of Reality in the Child. New York: Ballantine Books.

Raithelhuber, E. (2012). "Ein relationales Verständnis von Agency. Sozialtheoretische Überlegungen und Konsequenzen für empirische Analysen," in Agency. Qualitative Rekonstruktionen und gesellschaftstheoretische Bezüge von Handlungsmächtigkeit, eds S. Bethmann, C. Helfferich, H. Hofmann, and D. Niermann (Weinheim: Beltz Juventa), 122-153.

Ricken, N., and Wittpoth, J. (2017). "Sozialisation? Subjektivation? Ein Gespräch zwischen den Stühlen," in Pierre Bourdieu: Pädagogische Lektüren, eds M. RiegerLadich and C. Grabau (Wiesbaden: VS Verlag), 227-253.

Schadler, C. (2013). Vater, Mutter, Kind werden: Eine posthumanistische Ethnographie der Schwangerschaft. Bielefeld: Transcript.

Schadler, C. (2016). How to define ever transforming family configurations? A new materialist approach. J. Fam. Theory Rev. 8, 503-514. doi:10.1111/ jftr.12167

Schmitz, S. (2012). The neuro-technological cerebral subject: persistence of implicit and explicit gender norms in a network of change. Neuroethics 5, 261-274. doi:10.1007/s12152-011-9129-1

Schmitz, S., and Degele, N. (2010). "Embodying - ein dynamischer Ansatz für Körper und Geschlecht in Bewegung," in Gendered Bodies in Motion, eds N. Degele, S. Schmitz, M. Mangelsdorf, and E. Gramespacher (Opladen: Budrich UniPress), 13-36.

Schroeter, K. R. (2012). "Altersbilder als Körperbilder: doing age by bodyfication," in Individuelle und kulturelle Altersbilder. Expertisen zum 6. Altenbericht der Bundesregierung, eds F. Berner, J. Rossow, and K.-P. Schwitzer (Wiesbaden: VS Verlag für Sozialwissenschaften), 153-229.

Sen, A. (1993). "Capability and well-being," in The Quality of Life, eds M. Nussbaum and A. Sen (Oxford: Clarendon Press), 30-53.

Sewell, J. (1992). A theory of structure: duality, agency, and transformation. Am. J. Sociol. 98, 1-29. doi:10.1086/229967

Shildrick, M. (2013). Re-imagining embodiment: prostheses, supplements and boundaries. Somatechnics 3, 270-286. doi:10.3366/soma.2013.0098

Strand, P. S. (2000). Responsive parenting and child socialization: integrating two contexts of family life. J. Child Fam. Stud. 9, 269-281. doi:10.1023/A: 1026416922364

Tietze, W. (2008). "Sozialisation in Krippe und Kindergarten," in Handbuch Sozialisationsforschung, eds K. Hurrelmann, M. Grundmann, and S. Walper (Weinheim: Beltz Juventa), 274-289.

van der Tuin, I. (2008). Deflationary logic: response to Sara Ahmed's 'imaginary prohibitions: some preliminary remarks on the founding gestures of the new materialism?. Eur. J. Womens Stud. 15, 411-416. doi:10.1177/1350506808095297 White, G. (1977). Socialisation. London: Longman. 
Witz, A. (2000). Whose body matters? Feminist sociology and the corporeal turn in sociology and feminism. Body Soc. 6, 1-24. doi:10.1177/1357034X0000 6002001

Conflict of Interest Statement: The author declares that the research was conducted in the absence of any commercial or financial relationships that could be construed as a potential conflict of interest.
Copyright (c) 2017 Höppner. This is an open-access article distributed under the terms of the Creative Commons Attribution License (CC BY). The use, distribution or reproduction in other forums is permitted, provided the original author(s) or licensor are credited and that the original publication in this journal is cited, in accordance with accepted academic practice. No use, distribution or reproduction is permitted which does not comply with these terms. 